\title{
Agricultural region development: problems, tax threats, potential
}

\author{
E A Murzina ${ }^{1, *}$, and $M S$ Shemyakina ${ }^{1}$ \\ ${ }^{1}$ Volga State University of Technology, Lenin Square 3, 424000, Yoshkar-Ola, Russia
}

\begin{abstract}
The article is devoted to the problem of the development of the agro-industrial region. Economic, geopolitical relations, crisis situations, risks of the state and enterprises require the study of methodological support for new functions of tax administration of agribusiness enterprises. The economic security of public law education characterizes the state of the tax system and tax potential, which ensure the sustainable development of the territory. The authors investigated the purpose of tax potential management, one of which is the assessment of the security of the tax territory. For management and assessment, a tree of goals was built, based on the hierarchical principle of presenting promising goals for managing the economy of an agricultural region. The general goal and objectives of two levels are determined. The authors determined that the process of making management decisions to ensure tax security of the territory should consist of five stages. At the same time, the end result of the assessment should be a tax security strategy. A correlation analysis of a number of factors was carried out, among which the formation of the onset of risks and representing the main threat to the tax security of the territory incomplete provision of tax revenues at all levels of the budget system was revealed. Calculations were made on the example of the administrative territory of the Russian Federation (Republic of Mari El).
\end{abstract}

\section{Introduction}

The economic security of agribusiness enterprises is an important issue and is being studied by a wide range of scientists around the world, including Russian experts [1]. In the works of scientists from other countries, the tax component is mainly studied in the framework of ensuring the economic security of the territory. For example, the Institute for Social and Political Research (New Haven) calculates the Economic Security Index [2-3].

Another approach is to study tax security not at the state level, but at the level of agroindustrial corporations. Thus, the Internal Revenue Service (IRS) views tax security from a taxpayer's perspective and is based on improved authentication procedures, improved information sharing, increased cybersecurity, and increased education and outreach.

In our opinion, socio-economic security and its assessment are directly related to the sustainable development of the territory. In this regard, the forecast of the onset of unfavorable situations (risks) and the practical assessment of the influence of factors that

\footnotetext{
* Corresponding author: elena.murzina@gmail.com
} 
form the main threats to the tax security of the territory should be based on the macroeconomic indicators of the development of this territory. It is necessary to analyze the influence of such indicators on the formation of the tax base when using the legislatively established tax mechanism. The results of such an assessment and the management decisions adopted in accordance with it will reduce the threats to the tax security of the territory with priority agricultural production. The aim of the study is to study the function of managing tax potential in agricultural regions, one of which is the assessment of the security of the tax territory. In this connection, it is necessary to conduct a correlation analysis of a number of factors. This will help to identify risks and threats to the tax security of the territory. Testing of the proposed methodology is carried out on the example of the administrative territory of the Russian Federation (Mari El Republic).

\subsection{Problem Statement}

In agricultural regions management of tax potential is currently carried out through the implementation of the functions of tax administration by the tax authorities of the state and its territorial departments. Tax administration should be considered in a wide range of tax relations: in the implementation of tax policy, in the relationship of tax authorities with taxpayers, in monitoring the implementation of the tax mechanism and in managing tax potential. This approach allows us to consider the functions of tax administration (tax planning, taxpayer accounting, tax control, analysis, tax regulation, work with taxpayers and tax monitoring [4] as management functions, including tax potential management.

The need to develop the existing functions of tax administration, their content, the allocation of new system and target tasks determine economic, geopolitical relations, crisis situations, risks of the state and taxpayers. To such tasks in modern conditions should include the task of ensuring tax security [6]. The tax potential is a kind of "airbag" in the economic development of the region and its territories, which is explained from several perspectives:

Firstly, a well-defined structure of tax potential and an effective methodology for planning tax payments is a key information basis for budgetary security, determined on the basis of possible tax revenues to budgets of all levels. The structure of the tax potential should be determined based on the current state of tax bases, their development trends, due to the growth of production volumes and business value.

Secondly, the effectiveness of tax payment planning is determined by: a comfortable tax environment in which taxpayers tax culture is maintained and multiplied; reducing tax risks and achieving the optimal level of tax burden, combined with the planned and forecasted level of profitability of the taxpayer organization. Such a tax environment may be characterized by a sufficient level of tax security [7].

Thirdly, the generated tax potential requires an assessment not only of the planned and forecast values used in its formation, but also of the actual data on the tax revenues of the territory that provide the budget and its revenue [8].

\section{Material and methods}

A comparative analysis of the forecast and actual data on the tax potential of the agricultural regions makes it possible to identify specific areas of management for which decisions are required regarding the prevention of tax risks and increasing the level of tax security [9]. For management and evaluation, an objectives tree is constructed (Fig. 1), which is based on the hierarchical principle of representing promising goals for managing tax potential. An important goal of managing tax potential is the regulation of intergovernmental relations. It should be noted that the tax potential of the territory is 
inextricably linked with the norms of distribution of tax resources between budgets - tax revenues of a certain level of the budget system depend on their size, and based on the tax potential index, inter-budget equalization is carried out.

Determining effective methods of managing state and municipal finances, assessing the balance of the budget and determining a long-term budget strategy are necessary for regulating the financial and budget sphere [10-11].

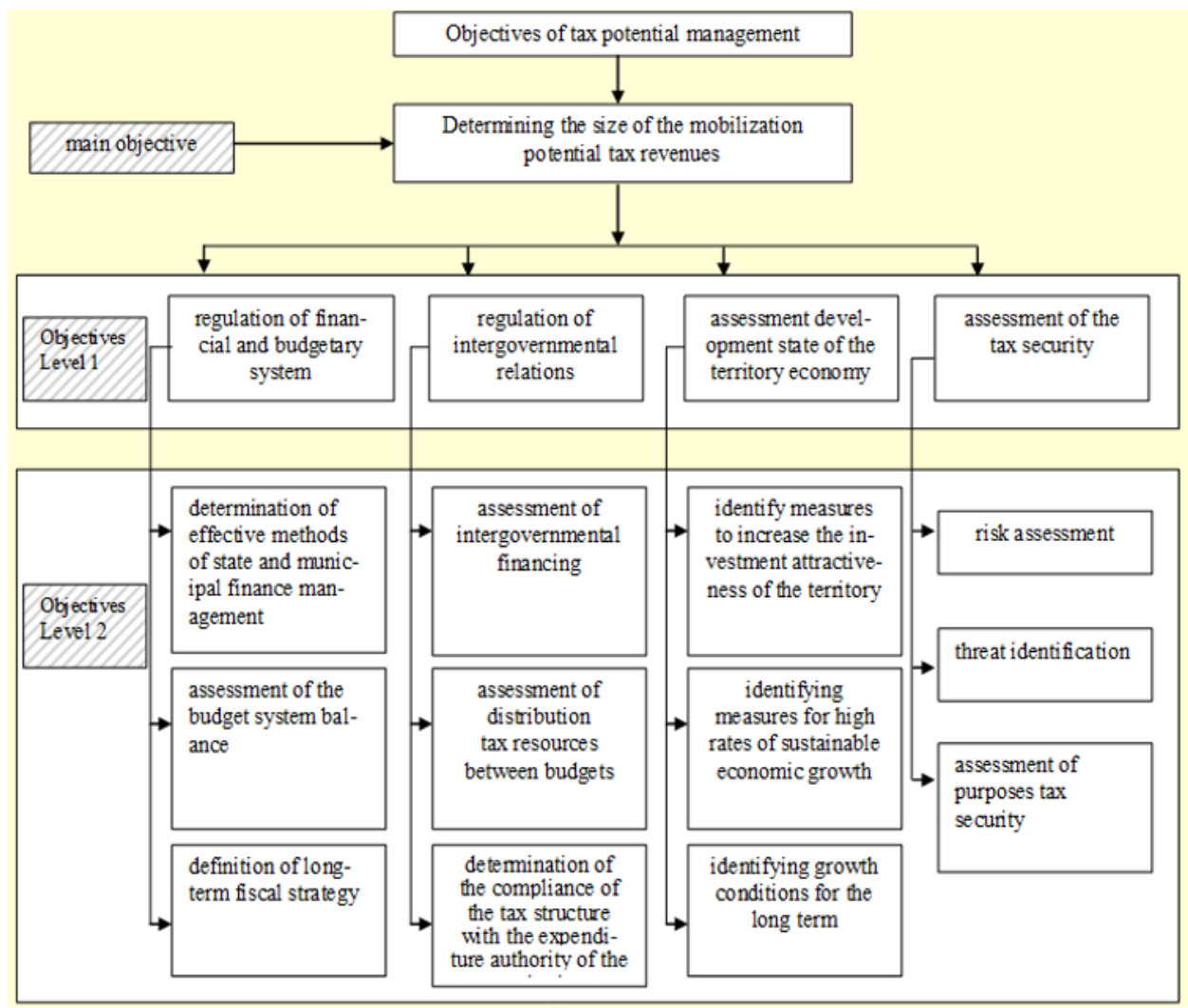

Fig. 1. Objectives tree in the process of managing the tax potential of the territory (author's research).

The objectives of the first level include assessment of the tax security of the territory, which should be understood as the state of the tax system and tax potential, ensuring sustainable development of the territory. The study of this category involves the distinction of such concepts as threats and tax security risks.

Under the threats to the tax security of the territory, we understand the totality of conditions and factors that create a danger to the important interests of the state in the field of formation of tax potential.

Tax security risks are adverse uncertainties that create conditions and form danger factors for the interests of the state and territory [12-13]. It should be noted that all risks are formed in a certain environment: economic, legal, political, social, technological, etc. Moreover, the whole set of risks does not exist, but is in constant interaction, which explains: the appearance of a risk threat, the likelihood of a risk, an assessment of the consequences the onset of risk [14-18]. The most difficult in practice is the process of identifying risk.

Risks and the environment in which they arise differ in their degree of influence on the tax security of different territories. For example, the risk of a decrease in oil prices is 
especially relevant for regions with a large share of oil producing organizations, and its onset indicates the threat of the regional budget not being provided with income tax, and the federal budget with a mineral extraction tax.

For the basis of the initial data for analysis, the data of the Tax passport of the Mari El Republic were taken. A regional tax passport is a consolidated official document that reflects all information about tax revenues to the region's budget.

\section{Results and discussions}

A large amount of data was analyzed. We selected 25 factors contained in the tax passport of the administrative territories of the Russian Federation (Mari El Republic). As a result of the correlation analysis, factors have been identified that are forming in the economic environment and are related to the management of tax potential: In the event of adverse situations, factors create threats to the tax security of the territory (Table 1).

Table 1. Data for analysis.

\begin{tabular}{|c|c|c|c|c|}
\hline Factor name & $\begin{array}{l}\text { Factor } \\
\text { number }\end{array}$ & 2017 & 2018 & 2019 \\
\hline $\begin{array}{l}\text { gross domestic product } \\
\text { (billion dollars) }\end{array}$ & 1 & 906,1646 & 999,9538 & 1325,363 \\
\hline $\begin{array}{l}\text { the volume of shipped goods } \\
\text { of own production, works and } \\
\text { services performed by our } \\
\text { own mining operations } \\
\text { (billion dollars) }\end{array}$ & 2 & 174,7585 & 180,1846 & 211,6308 \\
\hline $\begin{array}{l}\text { the volume of shipped goods } \\
\text { of our own production, work } \\
\text { and services performed by our } \\
\text { own manufacturing industries } \\
\text { (billion dollars) }\end{array}$ & 3 & 491,7508 & 521,5077 & 574,3231 \\
\hline $\begin{array}{l}\text { the volume of shipped goods } \\
\text { of own production, work and } \\
\text { services performed by own } \\
\text { forces for the production and } \\
\text { distribution of electricity, gas } \\
\text { and water (billion dollars) }\end{array}$ & 4 & 71,48308 & 79,44615 & 79,93846 \\
\hline $\begin{array}{c}\text { agricultural output (billion } \\
\text { dollars) }\end{array}$ & 5 & 77,49538 & 86,55385 & 86,98462 \\
\hline $\begin{array}{l}\text { the amount of work performed } \\
\text { by the activity "Construction" } \\
\text { (billion dollars) }\end{array}$ & 6 & 91,46923 & 95,14462 & 116,0908 \\
\hline retail turnover (billion dollars) & 7 & 423,6677 & 435,6508 & 458,5231 \\
\hline $\begin{array}{c}\text { wholesale turnover of } \\
\text { wholesale organizations } \\
\text { (billion dollars) }\end{array}$ & 8 & 614,0108 & 768,3538 & 885,3262 \\
\hline $\begin{array}{l}\text { foreign trade turnover (billion } \\
\text { dollars) }\end{array}$ & 9 & 8,096923 & 7,196923 & 8,984615 \\
\hline $\begin{array}{c}\text { fixed investment (billion } \\
\text { dollars) }\end{array}$ & 10 & 223,9369 & 225,2277 & 245,6431 \\
\hline $\begin{array}{c}\text { balanced financial result } \\
\text { (profit minus loss) (billion } \\
\text { dollars) }\end{array}$ & 11 & 129,5646 & 178,2723 & 158,7769 \\
\hline $\begin{array}{l}\text { profit margin for profitable } \\
\text { organizations (billion dollars) }\end{array}$ & 12 & 173,1369 & 203,0062 & 188,8631 \\
\hline
\end{tabular}




\begin{tabular}{|c|c|c|c|c|}
\hline $\begin{array}{c}\text { loss amount of enterprises } \\
\text { (billion dollars) }\end{array}$ & 13 & 43,57231 & 24,73385 & 30,08615 \\
\hline $\begin{array}{c}\text { accounts payable (billion } \\
\text { dollars) }\end{array}$ & 14 & 598,8554 & 650,4631 & 684,3277 \\
\hline receivables (billion dollars) & 16 & 549,7908 & 570,0492 & 619,3477 \\
\hline $\begin{array}{c}\text { average monthly accrued } \\
\text { salary per employee }\end{array}$ & 18 & 34012,3 & 36745,7 & 690,8769 \\
\hline $\begin{array}{c}\text { labor force (economically } \\
\text { active population) (thousands } \\
\text { of people) }\end{array}$ & 19 & 76587,5 & 76630,0 & 76100,0 \\
\hline $\begin{array}{c}\text { - employed (thousands of } \\
\text { people) }\end{array}$ & 20 & 72323,6 & 72390,0 & 72140,0 \\
\hline $\begin{array}{c}\text { - unemployed (thousands } \\
\text { of people) }\end{array}$ & 21 & 4260,0 & 4240,0 & 3966,5 \\
\hline number of taxpayers (unit) & 22 & 158433950 & 166312758 & 168651992 \\
\hline number of legal entities (unit) & 23 & 4820432 & 4553818 & 4371335 \\
\hline number of individuals (unit) & 24 & 153613518 & 161758940 & 164280657 \\
\hline $\begin{array}{c}\text { region population (thousands } \\
\text { of people) }\end{array}$ & 25 & 146519,8 & 146804,4 & 146880,4 \\
\hline
\end{tabular}

The correlation results are presented in Table 2. The analysis shows that the following factors have the greatest impact on tax revenues: gross domestic product, volume of shipped goods of own production, retail turnover, wholesale turnover of wholesale organizations, foreign trade turnover, fixed capital investments, accounts payable, accounts receivable.

The following factors negatively influenced the assessment data: the number of legal entities, the number of labor force (economically active population), employed, unemployed. 
Table 2. Results of correlation assessment.

\begin{tabular}{|c|c|}
\hline Factor number & Effective sign - tax revenues \\
\hline 1 & 1,00 \\
\hline 2 & 1,00 \\
\hline 3 & 0,98 \\
\hline 4 & 0,69 \\
\hline 5 & 0,68 \\
\hline 6 & 1,00 \\
\hline 7 & 0,99 \\
\hline 8 & 0,91 \\
\hline 9 & 0,76 \\
\hline 10 & 0,99 \\
\hline 11 & 0,30 \\
\hline 12 & 0,21 \\
\hline 13 & $-0,42$ \\
\hline 14 & 0,90 \\
\hline 15 & 0,52 \\
\hline 16 & 0,99 \\
\hline 17 & 0,83 \\
\hline 18 & 1,00 \\
\hline 19 & $-0,97$ \\
\hline 20 & $-0,90$ \\
\hline 21 & $-0,99$ \\
\hline 22 & 0,80 \\
\hline 23 & $-0,90$ \\
\hline 24 & 0,81 \\
\hline 25 & 0,79 \\
\hline
\end{tabular}

\section{Conclusion}

The results obtained allow us to conclude that the management of tax potential, ensured through the implementation of the above functions of tax administration, helps to identify and identify risks that form in the tax relations management system and apply to all economic processes.

The onset of tax risks is closely related to threats to the tax security of the region, to which we attributed:

(a) threat of incomplete provision of tax revenues of the federal budget;

(b) threat of incomplete provision of tax revenues to the regional budget;

(c) threat of incomplete provision with tax revenues of the local budget.

Therefore, reducing and preventing tax risks, which can lead to threats to tax security, seems to be one of the main tools for managing the tax potential of the agricultural region.

The reported study was funded by RFBR, project number 19-010-00620. 


\section{References}

1. Mironova O, Shemyakina M 2017 Tax Security: monograph (Moscow: Unity Dana) p 463

2. Burkov A V, Murzina E A 2016 Analysis method of structural equation modeling Advances in Systems Science and Applications 4(16) 1-12

3. Commissioner of Internal Revenue. Retrieved September 17, 2019 https://www.irs.gov/individuals/taxes-security-together.

$\begin{array}{lllll}\text { 4. Economic security index. Retrieved } & \text { September 17, } 2019\end{array}$ http://www.economicsecurityindex.org.

5. Khanafeev F F 2008 Analytical support for managing the tax potential of a region: theory and methodology: monograph (Moscow: Publishing House "Prospect") p 232

6. Ozaki R S, Arnold W 1985 Japan's Foreign Relations: A Global Search for Economic Security (Boulder and London: Westview Press) 156

7. Shemyakina M S, Murzina E A, Yalyalieva T V 2019 Management of the territory tax potential to ensure its tax security Regional Science Inquiry XI (2) 59-72

8. Ermakova E A, Tyupakova N N 2018 Comprehensive classification of environmental taxes Bulletin of the Saratov State Social and Economic University 2(71) 122-130

9. Kerimov A T 2019 Features of the modern structure of tax receipts of economically developed countries Scientific notes of the Crimean Engineering and Pedagogical University 1 97-104

10. Lyapin A E 2017 The boundaries of the object of tax statistics in the interpretation of the system of national accounts Statistics and Economics 5 23-32

11. Nenkina O N 2018 Accounting and statistical systems and identifying the possibility of their harmonization Economics: yesterday, today, tomorrow 8(8A) 404-409

12. Polkhov P A 2018 Indirect taxes in the system of national accounts Petersburg Economic Journal 1 122-136

13. Pechenegina T A 2019 Modeling of price indicators of tax load on elements of GDP and GVA in SNA: for labor, for consumption, for profit Innovative development of the economy: trends and prospects $1270-280$

14. Sarmento J M 2018 What Changes in the ESA (Springer) 83-89

15. Olalla C Benito 2020 Competences for sustainability in undergraduate business studies: A content analysis of value-based course syllabi in Spanish universities The International Journal of Management Education 17(2) 239-253

16. Denisenko V, Trikoz E 2020 E3S Web of Conferences 17514013 doi:10.1051/e3sconf/202017514013

17. Duong V A T, Pushkareva L 2020 E3S Web of Conferences 16411011 doi:10.1051/e3sconf/202016411011

18. Malinovsky A, et al 2020 E3S Web of Conferences 164 1-11. doi:10.1051/e3sconf/202016411039 